JISTEM - Journal of Information Systems and Technology Management

Revista de Gestão da Tecnologia e Sistemas de Informação

Vol. 12, No. 3, Sept/Dec., 2015 pp. 627-646

ISSN online: $1807-1775$

DOI: $10.4301 / \mathrm{S} 1807-17752015000300007$

\title{
COMPETITIVE ADVANTAGE OF A FRANCHISEE IN THE SOFTWARE MARKET: THE CASE OF TOTVS
}

\section{Joelson Obregão Matoso}

Universidade Federal do Paraná, Curitiba, Paraná, Brasil

Gustavo Abib

Universidade Federal do Paraná, Curitiba, Paraná, Brasil

\begin{abstract}
In highly competitive technology markets, such as the market in which Enterprise Resource Management (ERP) service providers do business, it has become of fundamental importance to understand the factors that create competitive advantages. This paper presents the support from the theoretical frameworks offered by the Resource-based View (RBV) and the Market-based View (MBV) to attempt to explain the competitive advantage held by Totvs Curitiba, a franchise of Totvs, which in turn is a Brazilian company that is a market leader in ERP service provision. In methodological terms, this is a Case Study for which data was collected during interviews and by observation and review of secondary documentary sources. The results suggest that the franchise's market-leading position was built on a relationship, which is identifiable in the results of this study, between the strategies adopted, resources controlled and competences developed.
\end{abstract}

Keyword: Resources, Organizational Competences, Strategy, Competitive advantage, Software market.

\section{INTRODUCTION}

Attempting to understand how some firms outperform others is a central theme in the field of strategy studies (D'Aveni, Dagnino, \& Smith, 2010). Maintenance of superior performance over time is an indicator of sustained competitive advantage (Peteraf \& Barney, 2003). Although many different theories have been proposed over the years to explain this phenomenon, two approaches stand out from the crowd: the Resource-based view (RBV) and the Market-based View (MBV) (Ramos-Rodriguez \& Ruiz-Navarro, 2004).

According to the MBV the origin of superior performance lies in a firm's market position that allows it to defend or influence the competitive forces of the industry

Manuscript first received/Recebido em: 19/05/2014 Manuscript accepted/Aprovado em: 04/08/2015

Address for correspondence / Endereço para correspondência

Joelson Obregão Matoso, School of Management, 632, Lothario Meissner Ave. $2^{\text {nd }}$ floor. Curitiba Paraná, Brasil, 80210-170, +55 41 33604360, E-mail: jomatoso@msn.com

Gustavo Abib, School of Management, 632, Lothario Meissner Ave. $2^{\text {nd }}$ floor. Curitiba Paraná, Brasil, 80210-170, +55 41 33604488, E-mail: abib@ufpr.br 
(Porter, 1986), whereas those who defend the RBV claim that the advantage springs from the way an organization uses the resources it possesses or controls, when these resources are valuable, rare and difficult to imitate or substitute (Barney, 1991).

While these two approaches may appear opposed to one another, authors such as Wernerfelt (1984) consider that they are merely two sides of the same coin. In other words, while the MBV explains competitive advantage from the point of view of the market's influence, the RBV explains the same phenomenon on the basis of resources and capacities. Notwithstanding, this conclusion itself raises a series of questions, one of the most important of which is how to understand the way that the relationship between the influences of the market and the specific attributes of the firm (resources, competences, strategies) results in construction of a competitive advantage.

In the international literature, empirical studies that investigate the subject generally employ survey-based research methods, administering standardized data collection instruments to large samples of firms, investigating variables chosen to measure performance, the value of firms' resources in the market and the degree of influence exerted by industry forces (Makhija, 2003; Galbreath \& Galvin, 2008). These studies have arrived at a number of conclusions, including the following: in environments facing rapid change, resources offer the greatest potential for explaining performance (Makhija, 2003); the relative importance of resources or of industry factors varies depending on the sector investigated (Phua, 2006); and intangible resources are more important for explaining the performance of firms in service industries than for explaining the performance of firms in manufacturing industries (Galbreath \& Galvin, 2008).

While research into the RBV is an expanding field in Brazil, the subject is studied less there than in many other countries. The majority of research of an exploratory nature takes a quantitative approach and employs the case study strategy (Ribeiro, Costa, Mirutuba, \& Oliveira Neto, 2012; Batista, Costa, Vieira, \& Balbinot, 2007). Furthermore, it is undoubtedly true that few studies have dealt with the relationship between the RBV and the MBV. Research investigating either the relationship between resources and competences or between resources and performance is more common (Aragão, Forte, \& Oliveira, 2010). To date, there are no studies in the Brazilian literature, whether theoretical or empirical, that have investigated all of the following categories: resources, strategies, industry forces, competences and competitive advantage. In view of the above, this paper attempts to fill this gap in the theoretical literature.

In order to investigate how these categories are interrelated in practice, an empirical example was selected. The case chosen was Totvs, which is a firm that has demonstrated a sustained competitive advantage and operates in a rapidly-changing business sector - the software industry. More specifically, a franchise of the Totvs group, Totvs Curitiba, was chosen for study. The objective of this research was, "To understand how Totvs Curitiba built its competitive advantage, taking account of the strategies employed, industry forces and the competences and resources developed."

The results of this study contribute to advancing the theoretical basis of studies of $\mathrm{RBV}$ and $\mathrm{MBV}$ in Brazil and also have management implications, such as the identification of resources that are relevant to the construction of competitive advantages in the software industry. 


\section{LITERATURE REVIEW}

The theoretical framework on which this paper is built is drawn from work that presents and discusses concepts related to the five categories with which the study is concerned, namely, sustained competitive advantage, strategy, organizational competences, industry forces and resources and capacities.

\section{Sustained competitive advantage}

The definition of competitive advantage that is generally adopted in RBV research is that proposed by Peteraf and Barney (2003, p. 314), for whom "An enterprise has a Competitive Advantage if it is able to create more economic value than the marginal (breakeven) competitor in its product market.".

This definition is linked to their definition of economic value:

"The Economic Value created by an enterprise in the course of providing a good or service is the difference between the perceived benefits gained by the purchasers of the good and the economic cost to the enterprise." (Peteraf; Barney, 2003, p. 314).

According to Barney and Arikan (2001) and Peteraf and Barney (2003), the logic of generating competitive advantage can be expressed by the following statements:

1. Competitive advantage is expressed in terms of the ability to create relatively more economic value.

2. To create more value than its rivals, an enterprise must produce greater net benefits, through superior differentiation and/or lower costs.

3. This task generates a competitive advantage by having greater residual value for the same value delivered, generating economic rents.

4. The benchmark for comparison is the marginal competitor.

For the purposes of this study, competitive advantage was assessed in terms of two financial indicators, growth in turnover and market share, which were initially used as a criterion for choosing the case to be studied and then used to assess performance over time of that case.

Competitive advantage therefore has a direct relationship with organizational performance which in turn, according to Combs, Crook and Shook (2005), is composed of the elements accounting profits, market value and growth. These authors conducted a meta-analysis of studies published in the Strategic Management Journal from 1980 to 2004 and concluded that organizational performance is best expressed as an organization's financial performance, while elements of operational performance such as quality and innovation act as mediators of the relationship between a firm's resources and its organizational performance.

\section{Strategy}

There is no universally accepted definition of strategy, but the manner in which the concept is dealt with in the literature can be generically classified as follows: studies that describe the evolution of the concept of strategy over time (Whittington, 2002); studies that attempt to define a single concept, generally a broad definition (Chandler, 1962; Porter, 1999; Andrews, 2006); and studies that propose several different ways of seeing strategy (Mintzberg, 2006). 
The definition of strategy adopted for the purposes of this study has links to the systemic school of Whittington (2002), to strategy as pattern, from Mintzberg (2006) and to strategy as contingency, from Rouleau and Seguin (1995). The actual definition employed is from Andrews (1980), who considers that strategy is:

the pattern of decisions in a company that determines and reveals its objectives, purposes, or goals, produces the principal policies and plans for achieving those goals, and defines the range of business the company is to pursue, the kind of economic and human organization it is or intends to be, and the nature of the economic and non-economic contribution it intends to make to its shareholders, employees, customers, and communities. (Andrews, 1980, pp. 18-19).

According to Bulgacov, Souza, Prohmann, Coser and Baraniuk (2007), research into strategy focuses on four fundamental questions about organizational objectives: "what?", "for whom?", "how?" and "why?". Research into strategic content deals with the first two questions, while research into strategic processes is concerned with the last two questions.

Thus, in addition to adopting the concept of strategy as a pattern of decisions, this study will combine the following elements with this concept: markets, products and the strategic focus of research investigating strategic content; and the process-based view of the way in which decisions have been taken over time, typical of research investigating the strategic process.

\section{Organizational Competences}

The concept of organizational competence has its roots in approaches that see the organization as a broad collection of resources, which was one of the principal contributions made to the RBV by Penrose's work (1959). If an organization is basically a collection of resources and if the characteristics of these resources can generate competitive advantages (Barney, 1991), then definition of strategies should start from an in-depth understanding of the possibilities that these resources offer (Fleury \& Fleury, 2004).

During the 1990s, a specific type of competence, known as core competences began to figure in studies of strategy and gained acceptance. According to Prahalad and Hamel (1990), organizational competences are an organization's capacity to combine, mix and integrate resources into products and services, whereas its core competences are the result of an organization's collective learning, especially with relation to coordination and integration of a range of different technology flows and abilities.

Furthermore, Pralahad and Hamel (1990) state that to be considered a core competence, competences must possess three basic characteristics: (1) they must make an important contribution to the value perceived by the customer; (2) they must contribute to differentiating the firm from its competitors and be difficult to imitate; and (3) they must contribute to growth of the firm over the medium and long term.

Also starting in the 1990s, several classifications of competences were proposed with the aim of differentiating them. Mills et al. (2002), drawing on Prahalad and Hamel (1990), proposed the following categories:

Figure 1. 
Classification of Organizational Competences according to Mills et al.

\begin{tabular}{|c|c|}
\hline Type & Definition \\
\hline Essential Competences & $\begin{array}{l}\text { High competences and activities, at the corporate level, } \\
\text { which are key to the firm's survival and central to its } \\
\text { strategy. }\end{array}$ \\
\hline $\begin{array}{l}\text { Distinctive } \\
\text { Competences }\end{array}$ & $\begin{array}{l}\text { Competences and activities that customers recognize as } \\
\text { differentiating the firm from competitors and which provide } \\
\text { competitive advantages }\end{array}$ \\
\hline $\begin{array}{l}\text { Organizational } \\
\text { Competences or } \\
\text { business unit } \\
\text { competences }\end{array}$ & $\begin{array}{l}\text { Competences and key activities, expected of a firm's } \\
\text { business units }\end{array}$ \\
\hline $\begin{array}{l}\text { Supportive } \\
\text { Competences }\end{array}$ & Activity that is valuable to support a range of competences \\
\hline Dynamic Capacities & $\begin{array}{l}\text { A firm's capacity to adapt its competences over time. } \\
\text { Directly related to resources that are important for change }\end{array}$ \\
\hline
\end{tabular}

Note: Adapted from Mills \& Bourne (2002, p. 13).

The definition of organizational competences adopted for the purposes of this study is the extent to which an organization performs the activities necessary for success, when compared with its competitors (Mills \& Bourne, 2002), and which are the result of its capacity to combine, mix and integrate resources into products and services (Prahalad \& Hamel, 1990).

\section{The Resource-based View - RBV}

The RBV comprises a set of propositions for explaining competitive advantage and it is the result of the work of several different authors (Ricardo, 1817; Selznick, 1957; Penrose, 1959; Demsetz, 1973), although the principle postulates of the approach were defined in work by Wernerfelt (1984) and Barney (1991). following:

According to Barney (1991), the resource-based approach assumes the

1. Firms in the same industry (or firms in a strategic group) may be heterogeneous in terms of the strategic resources they control;

2. These resources may not be perfectly mobile across firms and therefore heterogeneity may be long lasting.

With regard to the first premise, Rumelt (1984) claims that firms in the same industry substantively compete with different sets of resources using distinct approaches. These firms are differentiated by different histories of strategic choices and performance and because managers appear to maintain asymmetrical competitive positions.

With relation to the second premise, Peteraf (2003) claims that resources can be perfectly immobile when they cannot be sold, or imperfectly mobile when they can be sold, but that they will be more valuable when they are employed within the firm than when employed by competitors; in other words, when they are at least to a certain extent specialized to the requirements of the firm that possesses them. Additionally, according 
to Teece (1986), co-specialized resources can also exist, which are assets that, when employed in conjunction with other resources, have a high economic value.

Barney (1991, p. 105) proposed four criteria to indicate the extent to which a resource is unique and imperfectly mobile:

\begin{abstract}
a firm resource must have four attributes: (a) it must be valuable, in the sense that it exploits opportunities and or neutralizes threats in a firm's environment; (b) it must be rare among the firm's current and potential competitors; (c) it must be imperfectly imitable, and (d) there cannot be strategically equivalent substitutes for these resources that are valuable but neither rare or imperfectly imitable.
\end{abstract}

Additionally, according to Barney (1991) a resource that has the four characteristics above must also be capable of being exploited by the firm's organizational processes. The attributes value, rarity, imitability, organizational and substitutability have come to be known as the VRIOS attributes.

According to Barney (2007), if a resource or capacity is valuable, rare and costly to imitate, then exploiting this resource will lead to a sustained competitive advantage. In such a case, competitor firms face a significant cost disadvantage to directly duplicate successful capacities and resources and will not easily find existing substitutes for these resources. These types of resources and capacities are an organization's strong points and are sustainable distinctive competences.

\title{
3. THE MARKET-BASED VIEW - MBV
}

The most important contributions to the Market-based View are to be found in work by Porter $(1980,1985)$, who borrowed certain concepts of Industrial Organization, such as industry forces and barriers to entry. He adapted these concepts to the field of strategic management, with implications for strategists.

The principal concepts of the MBV are industry forces, analysis of the competition, generic strategies and value chain management. However, studies comparing the RBV with the MBV have only used the concept of industry forces from the second of these two approaches (Spanos \& Lioukas, 2001; Makhija, 2003; Galbreath \& Galvin, 2008). It is important to point out that the present study will do the same.

The five forces model proposed by Porter (1986) starts from two basic ideas. The notion that the level of competition in an industry depends on five basic competitive forces and the idea that the combination of these forces determines the industry's overall potential for profit, measured in terms of long term return on capital invested (Porter, 1985).

According to Porter (1986), the five forces that determine the structural conditions of an industry are as follows: the threat of new entrants; the intensity of rivalry between existing competitors, the threat of substitute products, the bargaining power of buyers and the bargaining power of suppliers.

Porter (1986) states that the target of a business unit's competitive strategy within an industry should be to find a position within that industry, from which the firm can best defend itself against these competitive forces or influence them in its favor. 
Considering that all five competitive forces in conjunction determine the intensity of competition in the industry, and also profitability, from the point of view of formulation of strategies, analyzing the greatest force or forces becomes crucial (Porter, 1986).

\section{Integrating the RBV and the MBV}

Although the MBV and RBV approaches are based on competing hypotheses, they are increasingly being used as complementary elements in a more complete theory of strategic management, which is still under development (Walter, Bandeira-de-Mello, \& Götze, 2005).

Mikus (2003) claims that any proposal for integration should consider the sequence in which the approaches will be made compatible with each other. As such, she considers that business processes and the "central competences" approaches are promising instruments for integration, because business processes offer an interface between the two approaches. These instruments are represented in the MBV by the "value chain" and in the RBV through organizational routines and competences.

However, Börner (2000) points out that whereas the RBV "value chain" is specific to each firm and should be exploited through market positioning, the MBV analysis is based on the position targeted by the firm, which in turn is defined by industry structure. Depending on the generic strategy chosen, the existing "value chain" should be restructured. As a result, the value chain can be considered an "independent variable" for the RBV, but a dependent variable for the MBV, throwing up a barrier to using value chains as an integrative element between the two views (Börner, 2000).

Acur and Bititci (2004) accepted Börner's recommendation (2000) and examined the links between market factors and firm resources in three previously published crosssectional case studies from the manufacturing industry in the United Kingdom. They concluded that in all three cases there were major benefits to be gained from relating central competences to internal resources with a focus on business processes. Although the results were considered exploratory, the authors concluded that they offered a comparative analysis of how market-based strategies are related to and integrate with resource-based strategies, through business processes.

Therefore, as recommended by Mikus (2003), Börner (2000) and Acur and Bititci (2004), this paper presents a case study of a market-leading firm integrating the $\mathrm{RBV}$ and the MBV by means of organizational competencies, which will be described in the remainder of the paper.

\section{METHODOLOGY}

The relationships between the categories analyzed in this paper are shown in the figure below: 
Figure 2. Relationships between categories of analysis.

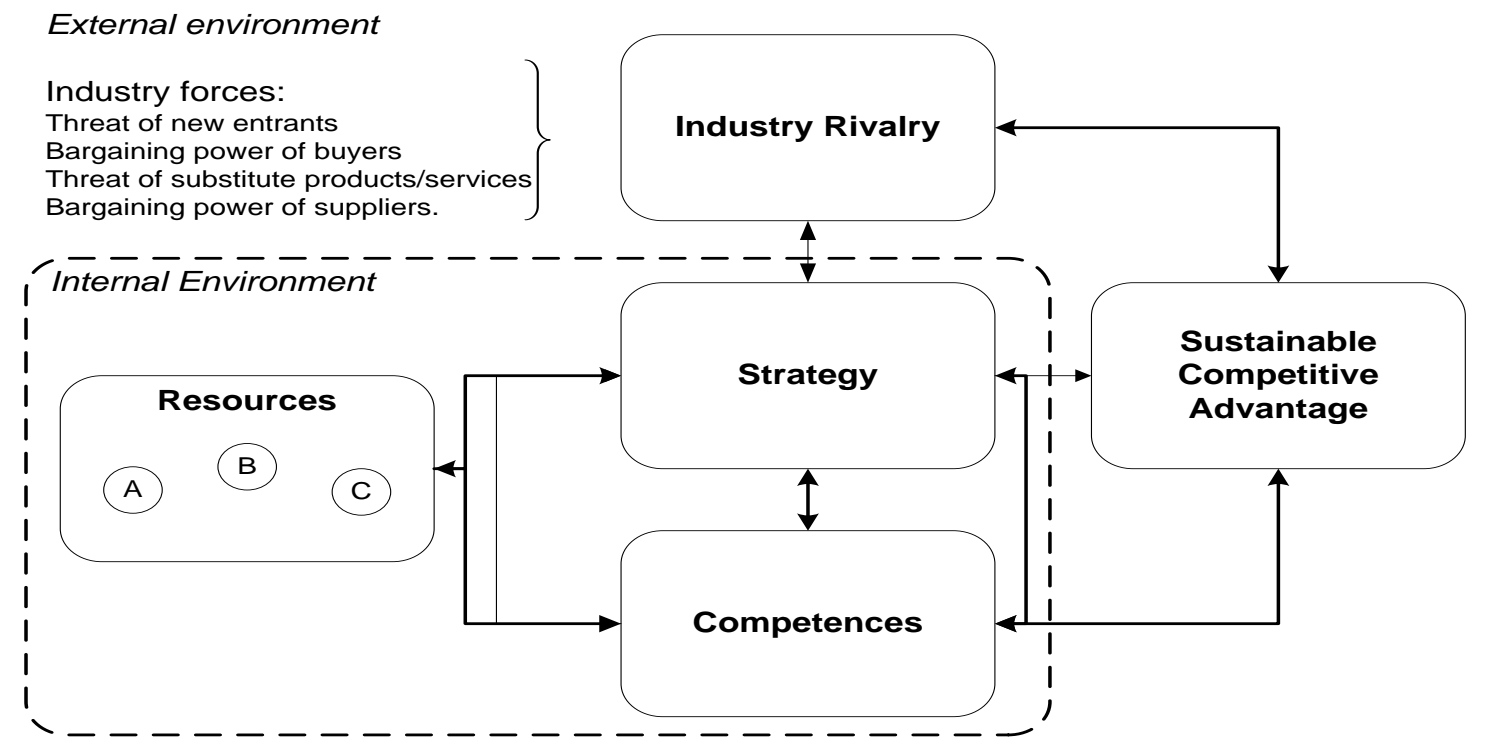

Note: Source: The authors.

As illustrated in the figure, it is assumed that strategy is based on the profile of organizational resources (Barney, 1991), on the organizational competences developed (Fleury \& Fleury, 2004) and on the influence of the level of market competition (Porter, 1980). The influence of each of these categories forms a positive feedback system since implementation of strategies influences industry forces and creates new resources and competences, which in turn will influence development of new strategies (Porter, 1980; Fleury \& Fleury, 2004).

In turn, competitive advantage can be directly related to strategy (Porter, 1980; Barney, 1991), or to competences (Fleury \& Fleury, 2004) or core competences (Prahalad \& Hamel, 1990).

Industry competition has a direct effect on industry profit margin and an indirect effect on organizational competitive advantage, since firms which have market power (a type of competitive advantage) can also influence the intensity of competition (Porter, 1980).

These multiple relationships of causality are part of the complex relations that are an integral part of sociocultural systems (Bulgacov \& Bulgacov, 2009), although this study is not focused on relationships of causality, but on the process through which these categories are related (Creswell, 2010).

In terms of study design, this is descriptive-exploratory research with a qualitative approach and a case study strategy, employing cross-sectional data collection. Notwithstanding, it also draws on a longitudinal analytical perspective which provides greater richness of information on aspects related to firm idiosyncrasies (Hoskinsson, Hitt, Wan, \& Yiu, 1999).

The case investigated was the Totvs Curitiba franchise. However, when necessary to explain the competitive advantage enjoyed by Totvs Curitiba, Totvs S.A. was also studied. The firm chosen combines all three of the characteristics that Yin (2010) considers justifying the study of a single case, since (1) this is a market-leading company (which makes it appropriate for testing the theories proposed); (2) according 
to Mercado Digital (2009), this position of leadership is an exception among markets in which the global sector leader SAP does business (making it a rare or extreme situation); and (3) there are few published studies about the resources in the ERP industry in Brazil (which means that this is a revealing case).

With regard to data collection, Yin (2010) states that six types of data sources are generally used when conducting case studies: documentation, archival records, interviews, direct observation, participatory observation and physical artifacts. The research described here employed three of these sources: documents, interviews and direct observation.

Interviews were conducted from October to December 2012 with 10 employees of the franchise (the president, four directors, three coordinators, one manager and one technician), 8 customers (from industries and firms of sizes that are representative of the franchise's customer portfolio) and one specialist in the IT industry, from Softex.

In contrast, data on Totvs S.A. were collected from documents provided by the franchise, articles about the company available on specialist sites and institutional bulletins from the company's website.

Data were subjected to content analysis by means of descriptions of all of the interviews and classification of dialogues by themes, as suggested by Bardin (2009). The analysis process comprised three stages: i) meticulous reading of the textual data; ii) an analysis, going from general to particular and in chronological order, attempting to trace the linkage of evidence; and iii) final classification of the data from interviews, documents and observations. The following categories were employed for the third of these stages:

Figure 3:

Categories used in content analysis.

\begin{tabular}{|c|c|c|}
\hline CATEGORY & $\begin{array}{l}\text { SUPPORTING } \\
\text { REFERENCES }\end{array}$ & SUB-CATEGORIES \\
\hline INDUSTRY FORCES & Porter (1986) & $\begin{array}{l}\text { Competitors, Substitute } \\
\text { products, Customers, } \\
\text { Suppliers and New } \\
\text { products/services. }\end{array}$ \\
\hline $\begin{array}{l}\text { RESOURCES AND } \\
\text { CAPACITIES }\end{array}$ & Barney (1991) & $\begin{array}{l}\text { Value, Rarity, Imitability, } \\
\text { Organization and } \\
\text { Substitutability. }\end{array}$ \\
\hline STRATEGIES & Andrews (2006) & None. \\
\hline $\begin{array}{l}\text { ORGANIZATIONAL } \\
\text { COMPETENCES }\end{array}$ & Mills et al. (2002) & $\begin{array}{l}\text { Core, Distinctive, } \\
\text { Organizational, Supportive } \\
\text { and Dynamic. }\end{array}$ \\
\hline $\begin{array}{l}\text { COMPETITIVE } \\
\text { ADVANTAGE }\end{array}$ & Peteraf and Barney (2003) & $\begin{array}{l}\text { Financial indicators of } \\
\text { growth and market share. }\end{array}$ \\
\hline
\end{tabular}

Note: Source: the authors. 
Certain precautions were taken to ensure validity and reliability. Construct validity was strengthened by the use of multiple data sources (documents, interviews and direct observation), while validity was ensured by the theoretical framework used for description of the categories and analysis of the relationships between them, which also makes it possible for the study to be replicated in other contexts using the same theoretical foundations.

Finally, with the objective of guaranteeing reliability, a dedicated research protocol was formulated, containing the data collection procedures, research questions, fieldwork observations and interview records. All of the results were analyzed and approved by the interviewees.

\section{DESCRIPTION OF THE CASE}

Totvs S.A. is a publicly listed company that does business in the software, services and technology market. It is the market leader in Brazil, with a 53.1\% market share and is also Latin American market leader with a $35.6 \%$ share. It is the largest producer of software and applications based in an emerging economy and the sixth largest in the world. It was established in 1983 and was the first company in the industry to be floated in Latin America. It currently has 10 thousand employees and has a presence in 23 different countries (http://www.totvs.com/sobre-a-totvs/principiosinstitucionais).

The most important events in the company's history were as follows: $1989-$ conception of a software distribution model based on franchises, similar to the distribution model used by Boticário; 1996 - ISO 9001 certification; 2004 - acquisition of Logocenter; 2005 - acquisition of RM Sistemas; 2008 - acquisition of Datasul; 2009 - revenues of $\mathrm{R} \$ 1$ billion.

Currently, the company owns five units in Brazil and has 52 franchises (http://www.totvs.com/ri). Each franchise has geographical exclusivity, i.e., just one franchise is allowed to do business in each predefined area, which may be an entire state or a region in which there are many different towns and cities. The franchises' revenues come from sale of services to customers and from commission on the sale of software licenses and monthly maintenance contracts, paid directly to Totvs S.A. Franchises are given ongoing education and training in new technologies in addition to administrative and marketing support.

There are three Totvs franchises in the Brazilian state of Paraná (http://www.totvs.com/ri), one based in the city of Londrina, serving the Northwest of the state, another in Foz do Iguaçu, serving the Southwest, and the third in Curitiba, serving the Northeast and Southeast of the State.

The third of these, Totvs Curitiba, started doing business in 1995, as a Microsiga franchise, but in 2008 it became a Totvs franchise, taking over the activities of two competitors: Logocenter and RM Sistemas.

The firm currently has around 170 employees and primarily serves the manufacturing, civil engineering and construction and retail industries. Its primary products are the ERPs Protheus (formerly Microsiga), Datasul, RM and Logix. The last three of these are ERPs from firms that were acquired by Totvs over the years. 


\section{RESULTS}

Considering that the objective of this research was to investigate which organizational competences, strategies, resources and industry forces contributed to building the competitive advantage of the case under investigation, the initial task was to describe the components of these categories using guiding questions, which led to the results illustrated in the figure below.

Figure 4. Relationships between competitive advantage, organizational competences, strategies, resources and industry forces in the case investigated.

QUESTION: How the Totvs Curitiba competitive advantage was build, considering the organizational competences, the adopted strategy, the resources and the Market structure?

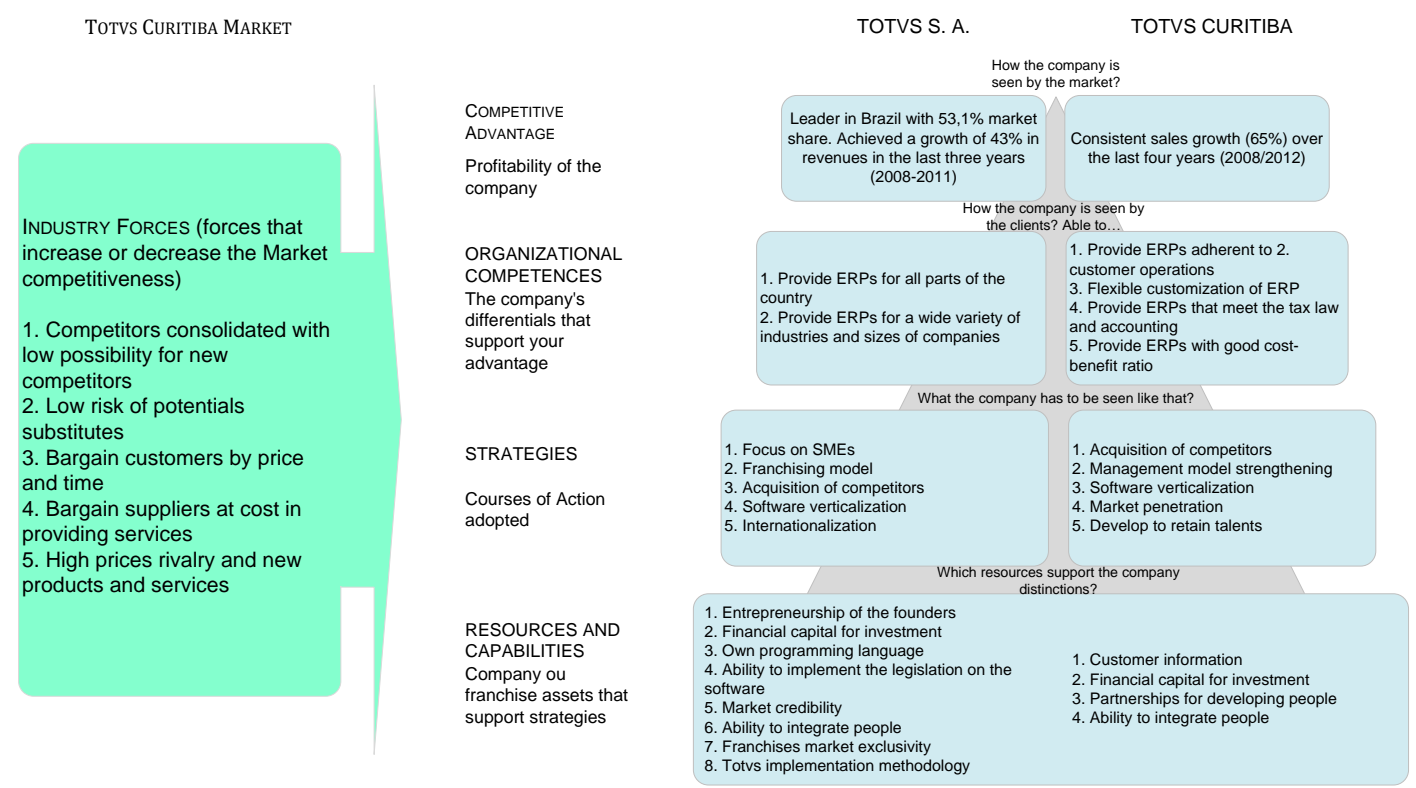

Note: Source: Research data

The starting point for the analysis was the competitive advantage which, in the case of Totvs S.A., is expressed as its $43 \%$ growth in revenues over the last 3 years. In case of the franchise, growth over the last 4 years has been $65 \%$. The reason why the franchise has shown greater relative growth is that the mergers and incorporations happened first at Totvs S.A. and were only cascaded to the franchises after a certain time had elapsed.

In order to achieve the competitive advantage that it now has, the firm had to develop competences to a higher level than its competitors. According to Fernandes, Fleury and Mills (2006), organizational competence consists of mobilization of resources, and its application will appear in performance.

Three of the six competences identified in Totvs S.A. and the franchise supplying ERPs to all regions in the country, supplying ERPs to a wide variety of industries and different sized firms and providing ERPs that meet tax and accounting legislation - have the characteristics of core competences proposed by Prahalad and Hamel (1990). In other words, (1) they are directly related with the firms' strategies; (2) they contribute to the value perceived by the client, particularly in the case of small and medium enterprises (SMEs) who get access to ERPs at prices that larger suppliers cannot offer; (3) they are considered as differentiating the firm from competitors and are 
difficult to imitate; and (4) they contribute to firm growth over the medium and long term.

While the other three of the franchise's competences do not have the attributes of core competences, they can be considered distinctive competences, since they differentiate the firm in the market (Mills \& Bourne, 2002; Prahalad \& Hamel, 1990). However, both the core competences and the distinctive competences of Totvs S.A. helped to win over new customers and stimulate acquisition of resources in the market by selling or by increasing the value of shares, while with relation to the franchise, customers highlighted these factors of differentiation as reasons for choosing Totvs as a partner for their businesses.

In turn, construction of competences is influenced by the firm's strategic actions, in other words by the decisions it makes in relation to products, markets and structure (Quinn, 1989). The first three strategies adopted by Totvs S.A. during its history (focus on SMEs, distribution through franchises and acquisition of competitors) were indicated as the reason for the company's success both in interviews with directors of the franchise and in secondary documents. Verticalization of software is a more recent strategy and although internationalization was adopted some time ago, it is only now becoming significant.

With regard to the franchise, five strategies were identified. Two of these originated with Totvs S.A. (acquisition of competitors and verticalization of software) and three were conceived of by the franchise. Two of these are related to structure (strengthening the management model and developing human resources) and one is related to the market (market penetration). As such, it is clear that although the franchise follows guidelines set by Totvs S.A., it also has the freedom to create its own strategies.

In turn, industry forces influence strategies in the following ways: (1) they are formidable barriers to entry making it difficult for new competitors to enter the market, which in turn means that market penetration strategies are prioritized; (2) substitute products do not represents a major risk, so improving current products and services is an important strategy; (3) buyers' bargaining power is high with relation to choosing an ERP, but low with relation to buying extra modules from the same product, meaning the verticalization strategy is advantageous; (4) suppliers' bargaining power is high, causing the firm to invest in improving its management model; (5) competition intensity with current rivals is high, leading the company to attempt to meet all of its current customers' demands and to seek niches to enter markets.

Having identified these strategies and the ways in which they are influenced by industry forces, the resources that sustain these actions were identified and evaluated, both for Totvs S.A. and for the franchise, because realization of the potential value of resources is dependent on how strategies are implemented and resources are exploited (Barney \& Arikan, 2001).

Ten resources were identified, two of which were common to both Totvs S.A. and the franchise, and two of which were developed exclusively by the franchise. Four of these ten resources have all of the VRIO attributes; in other words, they are valuable, they are rare, they are difficult to imitate, they are exploited by the organization and they are difficult to substitute.

The first of these VRIO resources is the entrepreneurial abilities of the founders and, primarily, of the current president of the company Laércio Cosentino. Decisions made by Laércio, such as to create the company in 1983 focused on software for microcomputers, to acquire its major competitors and to seek external and government 
financial support to achieve this, and to invest in a model of exclusive franchises, among others, demonstrate that this entrepreneurial ability possesses the VRIO attributes and it can be considered a co-specialized capacity (Teece, 1986). In other words, when this entrepreneurial ability is employed together with other resources and capacities, such as the capacity for investments, for example, it has a high economic value.

The second resource with VRIO attributes, the capacity to translate legislation into software, is crucial for firms that sell ERP in Brazil, since the country has 48 types of federal taxes, 5 state taxes and 10 municipal taxes (Impostômetro, 2013).

Whereas Totvs' competitors, SAP and Oracle, work with local partners, i.e., Brazilian companies that are responsible for translating changes to legislation into parameters for their ERPs, in a process that can be both slow and expensive, Totvs developed this competence internally and is able to provide its customers with all legal updates rapidly and with no additional cost.

The rarity and inimitability of this resource is demonstrated by the fact that the competitors have not been able to develop internal teams to perform this work, while the other VRIO attributes are explicit in the characteristics of this resource. The difficulty that competitors have to copy this resource may be associated with a causal ambiguity, in other words competitors find it difficult to understand the link between the resource and competitive advantage (Barney \& Clarck, 2007).

This failure of understanding legislation may be related to the fact that the capacity to understand and transpose it into the ERPs is a complex network of relationships between individuals, groups and technology, which Dierickx and Cool (1989) have identified as a stock of interconnected assets.

The third resource, the capacity to integrate people from the firms acquired by Totvs S.A., was developed over the course of more than 40 mergers and acquisitions that the company has accomplished, meaning that this too is a resource that is valuable, rare and particularly difficult to imitate. No other Brazilian company in its industry has accomplished as many incorporations as Totvs, which means the company is in possession of unique learning.

According to Barney and Clark (2007), firms that do not have resources that are dependent on space/time, as is the case of Totvs' experience with acquisitions and mergers, may never acquire them. As such, these resources become imperfectly imitable. The same authors state that unique historic conditions may occur when previous events in the evolution of a process have significant effects on subsequent events. This is what has happened to Totvs, which gradually reduced the time needed to accomplish mergers and acquisitions as it gained experience in these types of operation.

The fourth resource, offering exclusivity of markets to franchises was a strategy adopted in 1989 when the company divided Brazil into 44 regions and assigned each region to a franchise, thereby generating a legal resource that the franchises have exploited greatly (Editora Abril, 2012). This resource has all of the VRIO attributes and although it was later copied by competitors, it remained a factor of differentiation primarily because Totvs had been the pioneer, as one of the directors explains "[the competitors] arrived later..., But perhaps not everyone is an entrepreneur, not everyone has a vocation for negotiation; anyway, they arrived much later when we were already consolidated" (F 02).

Once more, in the case of market exclusivity, the resource is imperfectly 
imitable because of the unique historical condition that Totvs was the first to recognize and exploit the potential of this resource. As such they gained first-mover advantages, such as, for example, the advantage of consolidating distribution channels.

While the company's credibility in the market has all of the attributes necessary to become a source of competitive advantage, it is as yet little exploited by the franchise, since it could use the brand's reputation to sell other products that are already available from other Totvs franchises.

The methodology used to implement systems and the proprietary programming language are valuable, but not rare resources, since major players in the ERP market need these resources in order to compete in the industry.

Although financial capital is common in the market, it has a special character with relation to Totvs. In 2005, when the local software market began to face strong competition from multinational firms, the BNDES development bank decided to reinforce one Brazilian company and invested $\mathrm{R} \$ 400$ million in Totvs, giving it a unique historical advantage in the market.

Another resource, information about customers, which is only analyzed with respect to the franchise, is valuable, but common and easily imitated by competitors. This is because the practices necessary to obtain information about customers are known and adopted by the market, notwithstanding the fact that the franchise has organized its processes for exploiting this resource in a very efficient manner.

Finally, the franchise's partnerships for development of human resources, while valuable for developing human capital, are also common in the market and easy to replicate. Additionally, the franchise's processes, such as selection of employees, do not exploit all of the potential offered by these partnerships.

Since this company has a superior competitive advantage in the market, it had been expected that the strategies would be based on resources with the VRIO attributes (Barney, 1991). However, just four of the ten resources that appear to support these strategies have all of the VRIO attributes. The other six are common to several competitors or easy to imitate.

Barney (1991) has already claimed that the dimensions of resource attributes are multiplicative and not additive, but, according to Armstrong and Shimizu (2007), no studies had empirically tested this statement. As such, the results of the present study contribute to refining theory in the sense that even firms that do have a competitive advantage on the market support their strategies using resources with all of the VRIO attributes and also using resources, which do not possess all of the VRIO attributes.

In other words, while the framework proposed by Barney (2007) deals with the potential of resources to generate competitive advantage in isolation, this study assessed a collection of resources and their potential to generate advantage, concluding that a mixture of resources, some with all of the VRIO attributes and others with fewer of these attributes, can also generate sustained competitive advantage.

This result also partially supports a criticism of the RBV made by Newbert (2007) and Foss and Knudsen (2003), who claimed that the VRIO attributes are neither necessary nor sufficient to generate sustained competitive advantage. Partially, because in the case investigated, in addition to the firm having a sustained competitive advantage, strategies were used that were based on resources with all of the VRIO attributes and on resources without all of the VRIO attributes. 
Another conclusion that can be drawn from Figure 1 is that Totvs S.A. has more resources than the franchise. The strategies, differentiating factors, competitive advantage and resources with all VRIO attributes were all developed at Totvs S.A.

While this result may be expected with relation to firms operating in franchise systems, there are at least two implications of this finding. The first is that the fact that the VRIO resources are owned by Totvs S.A. presupposes that, in order to obtain competitive advantage, the franchise should bas its strategies on these resources belonging to Totvs S.A. rather than on its own resources. The second is that if the franchises were to be able, in line with Totvs S.A., to develop resources with VRIO attributes, it could considerably increase its chances of obtaining competitive advantage.

According to Porter (1986), industry forces have an influence on competitors' rivalry and on the potential for profit of an industry. As has been demonstrated, there is intense competition in the ERP market, primarily related to price and launching of new services and products, and the potential for profit in the market is considered high, as explained by an industry expert:

Customizable software (which includes ERP software) is the most profitable, and over recent years, it has gone from strength to strength. Among the many different economic sectors that make up what we call IBIS, customizable software is the most productive, in the sense that you can get the largest returns with the lowest number of people you need to employ, in terms of size and number of firms (Virginia Duarte, Manager at Observatório Softex).

When the relationship between industry forces and the competitive advantage held by the case is investigated on the basis of the premises of the MBV, the conclusion is that Totvs (both S.A. and the franchise) has a competitive advantage because of the following reasons:

1. It is able to prevent the entry of new competitors to the market by erecting entry barriers, such as economies of scale, need for capital, cost of change and access to distribution channels;

2. It does business in a market in which there are no substitute products that are a potential threat to the products and services it sells;

3. Once its buyers have acquired a product or service their bargaining power is no longer high because of the cost of change;

4. Suppliers' bargaining power is high because of the cost of services, but this condition is common to all of its competitors.

However, with the exception of first of these reasons, they are true of any competitor in the same market, which, to a certain extent, weakens the conclusion that industry forces alone explain the competitive advantage held by Totvs

In contrast, analyzing the case according to the premises of the RBV, it can be concluded that Totvs has a competitive advantage because:

1. It owns a selection of resources with all of the VRIO attributes, i.e., heterogeneous resources that are difficult for the competition to copy;

2. It bases its strategies on resources that have VRIO attributes, some with all of them others with fewer.

The second group of conclusions appears to offer greater potential for explaining competitive advantage in the case investigated because it is supported by all of the 
premises of the RBV, in contrast with the first group of conclusions which only echoes some of the premises of the MBV.

In general, the expected result can be confirmed, to the extent that the strategies of the franchise are based on resources with the VRIO attributes. This paper's contributions, however, go beyond this, since it can be concluded that: (a) The RBV had greater explanatory power than the MBV to explain the competitive advantage in the case investigated, which corroborates the results of earlier studies (Makhija, 2003; Phua, 2006; Galbreath \& Galvin, 2008); (b) It is useful to relate the RBV approach to a theory of environmental analysis (MBV) to define the value of resources, which is endogenous; in other words, it is dependent on the characteristics of the context (this was a requirement proposed by Barney [2001] and proved promising in the present study, since it combined the RBV not only with the MBV, but also with the organizational competences approach); (c) The franchise's strategies are based both on resources that have all of the VRIO attributes and also on resources that only have some of the VRIO attributes, which, to a certain extent, supports the criticism made by Newbert (2007) and Foss and Knudsen (2003) that the VRIO attributes are not necessary to create competitive advantage; and (d) The resources held by Totvs S.A. support the strategies of Totvs S.A., the majority of which are replicated in the franchise.

\section{FINAL COMMENTS}

The objective of this study was to understand how the competitive advantage of Totvs Curitiba was constructed, taking into consideration the strategies employed, industry forces, competences and resources exploited. However, once data collection was initiated, it was realized that since the case investigated was a franchise it would be necessary to also analyze the same categories in the franchiser. In response to this, the analysis was widened, making it possible, with certain precautions, to also explain the generation of competitive advantage by Totvs S.A.

From the point of view of the theoretical perspective adopted, whether to employ RBV or MPV to explain competitive advantage, it can be observed that if market forces affect all competitors in a similar manner, it is to be expected that all will defend themselves from these forces in the same way. In contrast, the influence of heterogeneous and immobile resources means a firm adopts a unique competitive posture.

In the ERP market, in which changes take place rapidly, management concern themselves more with strategies based on the resources they control than with strategies for positioning against industry forces. In other words, the RBV is more predictive for explaining competitive advantage in markets with high rates of change (Grant, 1991; Makhija, 2003), as is the case of the ERP market. This can be confirmed with reference to a study by May et al. (2014), who states that this industry has a high rate of change and geographical boundaries are not a competitive reference.

Notwithstanding, this does not mean that environmental analysis should be discarded; on the contrary, environmental analysis helps to isolate those factors that differentiate a firm in the market. Resources and capacities help to explain how these differentiating factors can be obtained (Barney, 2001). As such, the connection made in this study between the RBV, MBV and organizational competences proved highly promising for isolating those characteristics of the firm that make it unique in the 
market (competences recognized by the market) and for explaining how these characteristics were constructed over time (by development of strategies and resources).

In summary, the most important contributions of this study are as follows: (1) it has advanced RBV studies in Brazil; (2) it has advanced the discussion about the relative capacity to predict performance of the RBV and the MBV in rapidly changing environments; (3) it has integrated the RBV and the MBV with the organizational competences approach; (4) it has analyzed the way in which resources are shared in a company that works with franchises; and (5) it has identified resources and capacities in the ERP market.

With regard to research limitations, the fact that primary data relating to the Totvs Curitiba franchise were collected, but secondary data related to the Totvs S.A. franchiser were used means that the results of the case are not applicable to the franchiser or to other franchises in the group.

With regard to future studies, it is suggested that criteria to evaluate resources, capacities, competences and strategies be more clearly defined (Rugman \& Verbeke, 2002), since a resource, for example, can be developed by a strategy, transform into a core competence (a high capacity in certain activities) and then once more become a resource (reputation) that can be exploited by other strategies.

It would also be of great value to study how synergy between resources with all of the VRIO attributes and resources with just some of the VRIO attributes contributes to sustained competitive advantage. Another important avenue is to investigate the categories analyzed (advantage, competences, strategies, resources and industry forces) together with the category of organizational learning in order to better understand the relationship between these categories and construction of competences.

Finally, this study could be replicated in a multi-case study format to obtain a comparative analysis of all of the categories. One possible suggestion would be to analyze the three firms that together have $82 \%$ of the ERP market: Totvs, SAP and Oracle.

\section{References}

Acur, N., \& Bititci, U. (2004). A balanced approach to strategy process. International Journal of Operations \& Production Management, 24(4), 388-408.

Andrews, K. R. (1980). The Concept of Corporate Strategy, 2nd Edition. Homewood, IL: Dow-Jones Irwin

Andrews, K. R. (2006). O conceito de estratégia corporativa. O processo da estratégia. Conceitos, contextos e casos selecionados (4a ed., pp. 78-84). Porto Alegre: Bookman.

Aragão, L. A., Forte, S. H. A. C., \& de Oliveira, O. V. (2010). Visão baseada em recursos e capacidades dinâmicas no contexto brasileiro: produção e evolução acadêmica em dez anos de contribuições. Revista Eletrônica de Administração, 16(2), 373-396.

Armstrong, C. E., \& Shimizu, K. (2007). A Review of Approaches to Empirical Research on the Resource-Based View of the Firm $\dagger$. Journal of management,33(6), 959-986. 
Bardin, L. (2009). Análise de conteúdo (Edição revista e actualizada). Lisboa: Edições, 70.

Barney, J. (1991). Firm resources and sustained competitive advantage.Journal of management, 17(1), 99-120.

Barney, J. B. (2001). Is the resource-based "view" a useful perspective for strategic management research? Yes. Academy of management review,26(1), 41-56.

Barney, J. B., \& Arikan, A. M. (2001). The resource-based view: Origins and implications. Handbook of strategic management, 124-188.

Barney, J. B., \& Clark, D. N. (2007). Resource-based theory: Creating and sustaining competitive advantage. Oxford: Oxford University Press.

Batista, A. L., Costa, J., Vieira, G., Balbinot, Z., \& Positivo-UnicenP, C. U.(2007). Visão baseada em recursos: Análise da Produção Científica entre 2000 e 2006. XII Simpósio de Excelência em Gestão e Tecnologia.

Börner, C. J. (2000). Porter und der" Resource-based View. Wisu, 5(00), 689-693.

Bulgacov, S., \& Bulgacov, Y. L. M. (2009). Conteúdo e processo estratégico: formação, implementação, mudança e resultados. Trabalho apresentado no IV Encontro de Estudos em Estratégia, Recife.

Bulgacov, S., Souza, Q. R., Prohmann, J. D. P., Coser, C., \& Baraniuk, J. (2007). Administração estratégica: teoria e prática. São Paulo: Atlas, 10.

Chandler, A. D. (1962). Strategy and structure: Chapters in the history of the American enterprise. Massachusetts Institute of Technology Cambridge.

Combs, J. G., Crook, T. R., \& Shook, C. L. (2005). The dimensionality of organizational performance and its implications for strategic management research. In D. J. Ketchen \& D. D. Bergh (Eds.), Research methodology in strategic management. Elsevier.

Creswell, J. W. (2010). Projeto de pesquisa métodos qualitativo, quantitativo e misto. In Projeto de pesquisa métodos qualitativo, quantitativo e misto. Artmed.

D'Aveni, R. A., Dagnino, G. B., \& Smith, K. G. (2010). The age of temporary advantage. Strategic Management Journal, 31(13), 1371-1385.

David, R. (1817). On the principles of political economy and taxation. Murray.

Demsetz, H. (1973). Industry structure, market rivalry, and public policy.Journal of Law and economics, 1-9.

Dias, J., \& Becker, G. (2010). Desvendando a "Black Box": Utilização da Perspectiva Histórico-Longitudinal em Pesquisas na Administração. ANAIS do XXXIV ENANPAD. Rio de Janeiro-RJ.

Dierickx, I., \& Cool, K. (1989). Asset stock accumulation and the sustainability of competitive advantage: Reply. Management Science, 35(12), 1514-1514.

Editora Abril (2012). Revista Exame: As 100 marcas mais valiosas do mundo em 2012. São Paulo, SP.

Fernandes, B. H. R., Fleury, M. T. L., \& Mills, J. (2006). Construindo o diálogo entre competência, recursos e desempenho organizacional. RAE-Revista de Administração de Empresas, 46(4), 48-65.

Fleury, M. T. L., \& Fleury, A. (2001). Construindo o conceito de competência. Revista de administração contemporânea, 5(SPE), 183-196. 
Fleury, M. T. L., \& Fleury, A. C. C. (2004). Alinhando estratégia e competências. RAERevista de Administração de Empresas, 44(1), 44-57.

Foss, N. J., \& Knudsen, T. (2003). The resource-based tangle: towards a sustainable explanation of competitive advantage. Managerial and decision economics, 24(4), 291307.

Galbreath, J., \& Galvin, P. (2008). Firm factors, industry structure and performance variation: New empirical evidence to a classic debate. Journal of business research, 61(2), 109-117.

Grant, R. M. (1991). The resource-based theory of competitive advantage: implications for strategy formulation. Knowledge and strategy, 33(3), 3-23.

Hamel, G., \& Prahalad, C. K. (1990). The core competence of the corporation. Harvard business review, 68(3), 79-91.

Hoskisson, R. E., Hitt, M. A., Wan, W. P., \& Yiu, D. (1999). Theory and research in strategic management: Swings of a pendulum. Journal of management, 25(3), 417-456.

Impostômetro. (2013). Relação dos Tributos Cobrados no Brasil. Associação Comercial de São Paulo.

Makhija, M. (2003). Comparing the resource-based and market-based views of the firm: empirical evidence from Czech privatization. Strategic management journal, 24(5), 433-451.

May, M. R., Abib, G., Neto, P. J. S., Junior, J. E. P., \& Bulgacov, S. (2014). Efeito Governo e Certificação na Indústria Brasileira de Software. Revista de Administração FACES Journal, 13(2).

Mercado Digital. (2009). O mestre das fusões: Como o ex-estagiário Laércio Cosentino incorporou 21 empresas, criou um grupo de R 1 bilhão e desafiou gigantes como SAP e Oracle. Isto é Dinheiro.

Mikus, B. (2003). Strategisches Logistikmanagemet-Ein markt-, prozess-und ressourcenorientiertes Konzept, Dt. Univ. Verlag, Wiesbaden.

Mills, J., \& Bourne, M. (2002). Strategy and performance: competing through competences (Vol. 2). Cambridge University Press.

Mintzberg, H. (2006). Os 5 Ps da estratégia. In MINTZBERG, Henry; QUINN, James Brian \& GHOSHAL, S. O processo da estratégia (Vol. 3, pp. 26-32).

Newbert, S. L. (2007). Empirical research on the resource- based view of the firm: an assessment and suggestions for future research. Strategic management journal, 28(2), 121-146.

Penrose, E. T. (1959). The theory of the growth of the firm. John Wiley \& Sons.

Peteraf, M. A. (1993). The cornerstones of competitive advantage: a resource- based view. Strategic management journal, 14(3), 179-191.

Peteraf, M. A., \& Barney, J. B. (2003). Unraveling the resource- based tangle. Managerial and decision economics, 24(4), 309-323.

Phua, F. T. (2006). Predicting construction firm performance: an empirical assessment of the differential impact between industry- and firm- specific factors. Construction Management and Economics, 24(3), 309-320.

Porter, M. E. (1979). How competitive forces shape strategy. Harvard Business Review 57(2), 137-145, 1979. 
Porter, M. E. (1981). The contributions of industrial organization to strategic management. Academy of management review, 6(4), 609-620.

Porter, M. E. (1985). Competitive advantage: creating and sustaining superior performance. New york.

Porter, M. E. (1986). Estratégia competitiva: técnicas para análise de indústrias e da concorrência. Campus.

Porter, M. E. (1999). Competição-On Competition: Estratégias Competitivas Essenciais. 515 p. Rio de Janeiro: Campus.

Quinn, B. J. (1989). Strategic Change:'Logical Incrementalism'. MIT Sloan Management Review, 30(4), 45.

Ramos- Rodríguez, A. R., \& Ruíz- Navarro, J. (2004). Changes in the intellectual structure of strategic management research: A bibliometric study of the Strategic Management Journal, 1980-2000. Strategic Management Journal, 25(10), 981-1004.

Ribeiro, H. C. M., Costa, B. K., Muritiba, S. N., \& de Oliveira Neto, G. C. (2012). Visão baseada em recursos: uma análise bibliométrica dos últimos 11 anos. Revista de Ciências da Administração, 14(34), 39-59.

Rouleau, L., \& Seguin, F. (1995). STRATEGY AND ORGANIZATION THEORIES: COMMON FORMS OF DISCOURSE*. Journal of Management Studies, 32(1), 101117.

Rugman, A. M., \& Verbeke, A. (2002). Edith Penrose's contribution to the resource- based view of strategic management. Strategic management journal, 23(8), 769-780.

Rumelt, R. P. (1974). Strategy, structure, and economic performance. Harvard University Press.

Selznick, P. (1957). Leadership in administration: A sociological interpretation. Berkeley. Cal.

Spanos, Y. E., \& Lioukas, S. (2001). An examination into the causal logic of rent generation: contrasting Porter's competitive strategy framework and the resource- based perspective. Strategic management journal, 22(10), 907-934.

Teece, D. J. (1986). Firm boundaries, technological innovation, and strategic management. The economics of strategic planning, 187-199.

Walter, F., Bandeira-de-Melo, R., \& Götze, U. (2005). A integração entre a visão baseada em recursos e a visão baseada no mercado da vantagem competitiva: dificuldades e perspectivas. XXV ENEGEP-Encontro Nacional de Engenharia de Produção, 3196-3203.

Wernerfelt, B. (1984). A resource-based view of the firm. Strategic management journal, 5(2), 171-180.

Whittington, R. (2002). O que é estratégia? São Paulo: Pioneira Thomson Learning.

Wright, P., Kroll, M., \& Parnell, L. (2000) Administração estratégica: conceitos. São Paulo: Atlas.

Yin, R. K. (2010). Estudo de caso: planejamento e métodos. Porto Alegre, RS: Bookman. 